\title{
HUBUNGAN KEPERCAYAAN DAN TRADISI KELUARGA PADA IBU MENYUSUI DENGAN PEMBERIAN ASI EKSKLUSIF DI KELURAHAN SIDOTOPO, SEMAMPIR, JAWA TIMUR
}

\author{
Fifin Triana Enita Setyaningsih ${ }^{1}$, Farapti Farapti ${ }^{2}$ \\ ${ }^{1}$ Departemen Biostatistika dan Kependudukan, Fakultas Kesehatan Masyarakat \\ ${ }^{2}$ Departemen Gizi Kesehatan, Fakultas Kesehatan Masyarakat \\ Universitas Airlangga, Surabaya \\ Alamat korespondensi:Fifin Triana Enita Setyaningsih \\ E-mail: fifin.triana.enita-2016@fkm.unair.ac.id
}

\begin{abstract}
Exclusive breastfeeding is one effort made to suppress infant mortality rate. The failure of exclusive breastfeeding practices is closely related to the behavior of breastfeeding. Social culture brings about traditions and beliefs that are often used as guidelines for behavior in the community. Belief has formed into a thing that is beliefed and will be the basis for a person to behave. Tradition is obtained through generations and become individual habits. The purpose of this study is to assess the relationship between exclusive breastfeeding and belief and tradition. This is an analytic research with cross sectional approach. Random sampling technique was used. The population was all breastfeeding mothers who had babies aged 6-12months. The sample obtained were 57 respondents. The variables studied were breast feeding mothers' beliefs and traditions on exclusive breastfeeding. Beliefs about giving complimentary foods to infants and the breastfeeding-related traditions in the community were associated with the implementation of exclusive breastfeeding. Data analysis showed that there was a significant relationship between belief ( $p$ value $=0,045)$ and tradition ( $p$ value $=0,019)$ with exclusive breastfeeding in $R W X I$ of Kelurahan Sidotopo. In conclusion, there is a relationship between belief and tradition in society with practice of exclusive breastfeeding. It is recommended that all sectors address belief and traditions in the effort to support exclusive breastfeeding programs.
\end{abstract}

Keywords: Exclusive breastfeeding, beliefs, tradition, culture

\begin{abstract}
ABSTRAK
ASI eksklusif adalah salah satu upaya yang dilakukan untuk menekan angka kematian bayi. Kegagalan praktik pemberian ASI eksklusif sangat erat kaitannya dengan perilaku ibu menyusui. Sosial budaya membawa tradisi dan kepercayaan yang seringkali dijadikan pedoman berperilaku di masyarakat. Kepercayaan telah terbentuk menjadi hal yang dipercaya dan akan menjadi dasar seseorang untuk berperilaku. Tradisi diperoleh dari generasi ke generasi dan menjadi sebuah kebiasaan individu. Tujuan dari penelitian ini adalah untuk mengidentifikasi hubungan kepercayaan dan tradisi terhadap pemberian ASI eksklusif. Ini adalah penelitian analitik dengan pendekatan cross sectional. Teknik sampling yang digunakan yaitu sistem random sampling, dengan populasi adalah pada ibu menyusui yang memiliki bayi umur 6-12bulan. Besar sampel yang diperoleh sebanyak 57responden. Variabel yang diteliti adalah kepercayaan dan tradisi ibu menyusui terhadap pemberian ASI eksklusif. Kepercayaan tentang memberi makanan lain pada bayi dan tradisi terkait menyusui dikaitkan dengan dengan pelaksanaan pemberian ASI eksklusif. Analisis data menunjukkan ada hubungan yang signifikan antara kepercayaan $(p$ value $=0,045)$ dan tradisi $(p$ value $=0,019)$ dengan pemberian ASI eksklusif di RW XI kelurahan Sidotopo. Kesimpulan diketahui ada hubungan antara kepercayaan dan tradisi di masyarakat dengan pelaksanaan pemberian ASI eksklusif. Diharapkan bahwa seluruh sektor dapat mengatasi masalah terkait kepercayaan dan tradisi dalam upaya mendukung pelaksanaan program ASI eksklusif.
\end{abstract}

Kata kunci: ASI eksklusif, kepercayaan, tradisi, budaya

\section{PENDAHULUAN}

Salah satu hal yang dapat menentukan keberhasilan pembangunan kesehatan suatu negara adalah Angka Kematian Ibu dan Angka Kematian Bayi. Indonesia merupakan salah satu negara di Asia dengan jumlah Angka Kematian Bayi (AKB) yang cukup tinggi. Pemberian air susu ibu (ASI) adalah faktor penting dalam kelangsungan hidup bayi (Simbolon, 2006). 
Angka Kematian Bayi (AKB) dan Angka Kematian Neonatal (AKN) pada tahun 2016 di Jawa Timur relatif sangat kecil yaitu 24 kematian per 1000 kelahiran hidup, namun bila dihitung angka kematian absolut masih tinggi yaitu sebanyak 4.722 bayi meninggal pertahun dan sebanyak 5.196 balita meninggal pertahun di Jawa Timur (Dinkes Provinsi Jawa Timur, 2017). Dalam satu hari berarti sebanyak 13 bayi meninggal dan 14 balita meninggal.

Upaya menurunkan angka kematian bayi perlu adanya perhatian khusus bagi kesehatan bayi mulai dari perawatan ketika lahir hingga pemberian makanan yang baik. Makanan yang paling sempurna dan ideal bagi bayi baru lahir adalah ASI. Beberapa organisasi kesehatan dunia seperti World Health Organization (WHO) dan United Nations Children's Fund memberi anjuran untuk menyusui bayi Eksklusif yaitu bayi hanya diberikan ASI saja hingga berumur 6 bulan, tanpa makanan maupun cairan lainnya selain ASI (Mulyani, 2013). ASI mengandung komposisi utama yang dibutuhkan otak bayi untuk dapat tumbuh secara optimal. Selain itu ASI juga merupakan nutrien alami yang ideal bagi bayi (Roesli, 2009).

Data yang didapatkan dari Dinas Kesehatan Provinsi Jawa Timur, capaian bayi yang diberikan ASI Eksklusif di Jawa Timur tahun 2016 sebesar $74 \%$. Capaian tersebut mengalami peningkatan setelah sebelumnya berada pada angka 61,5\% di tahun 2011. Secara keseluruhan pencapaian di Jawa Timur 74\% belum memenuhi target yang telah ditetapkan yaitu $80 \%$. Di Provinsi Jawa Timur sendiri terdapat 23 kabupaten/kota yang belum mencapai target, namun begitu beberapa kabupaten/kota telah dapat mencapai target.

Angka pencapaian ASI eksklusif di Puskesmas Sidotopo, Surabaya, Jawa Timur masih cukup rendah yaitu 64\%. Angka tersebut masih berada dibawah standar nasional yang telah ditetapkan yaitu sebesar $80 \%$. Kondisi tersebut mencerminkan bahwa masih ada masalah yang dihadapi para ibu di wilayah kelurahan Sidotopo terkait pemberian ASI eksklusif.

Belum semua ibu menyusui mengetahui apabila kebutuhan nutrisi untuk bayi sampai usia enam bulan dapat dipenuhi dengan ASI saja. Lambung bayi baru lahir hanya dapat menampung cairan sebanyak 10-20ml (2-4 sendok teh). Kapasitas lambung bayi baru lahir masih sangat terbatas, sehingga bayi seharusnya hanya diberikan cairan dengan kandungan gizi dan volume yang sesuai yaitu ASI saja (Depkes R.I, 2009).

UNICEF Indonesia menyebutkan bahwa dari 5 juta anak yang lahir setiap tahun di Indonesia, lebih dari setengahnya tidak mendapatkan ASI secara optimal pada tahuntahun pertama kehidupannya (UNICEF, 2016). Hal ini menunjukkan bahwa ibu di Indonesia masih jarang yang melaksanakan ASI eksklusif. Alasan yang biasanya terjadi pada para ibu di Indonesia adalah adanya pengaruh budaya berkaitan dengan ASI eksklusif (Yusrina \& Devy, 2016).

Beberapa hal seperti pengetahuan, sosial budaya, psikologi, fisik, perilaku dan tenaga kesehatan terbukti berpengaruh terhadap perilaku ibu dalam memberikan ASI (Soetjiningsih, 2012). Sosial budaya menjadi faktor yang berperan dalam membentuk pola pikir masyasrakat. Ludin (2008), menyatakan keputusan ibu dalam menyusui bayinya dipengaruhi oleh budaya yang dianut.

Penelitian yang dilakukan Rhokliana, et.al. (2011), diketahui adanya hubungan antara sosial budaya masyarakat dengan keberhasilan ibu dalam menyusui bayinya. Sosial budaya di dalam masyarakat memunculkan beberapa tradisi serta kepercayaan yang mempengaruhi perilaku masyarakat tersebut.

Kepercayaan yang ada dalam keluarga membuat ibu mengikutinya meskipun sudah banyak informasi yang diperoleh dari tenaga kesehatan. Seperti penelitian yang dilakukan oleh Widodo (2006), diketahui bahwa adanya kepercayaan yang berkembang di dalam masyarakat tentang menyusui bayi dapat membuat bentuk payudara berubah, menjadi salah satu penyebab paling signifikan tidak berhasilnya pemberian ASI secara ekslusif.

Dari data yang diperoleh pada studi pendahuluan di kelurahan Sidotopo, diketahui bahwa mayoritas warga di kelurahan Sidotopo RW XI adalah para warga pendatang. Mayoritas pendatang adalah para warga dari suku Madura yang memilih menetap di Jawa. Warga di kelurahan Sidotopo masih kental dengan beberapa budaya yang dipercaya dan berkembang di masyarakat. Untuk itu dilakukan penelitian guna mengetahui apakah tradisi dan kepercayaan masyarakat berhubungan dengan kegagalan capaian ASI eksklusif di wilayah kelurahan Sidotopo. 


\section{METODE PENELITIAN}

Penelitian ini menggunakan metode analitik dengan pendekatan cross sectional. Metode tersebut digunakan untuk menganalisis suatu fenomena dengan melakukan pengamatan dalam satu waktu. Analisis dilakukan untuk mengetahui hubungan tradisi dan kepercayaan dengan pelaksanaan ASI eksklusif di RW XI kelurahan Sidotopo.

Populasi adalah ibu menyusui yang mempunyai anak berusia 6-12 bulan di kelurahan Sidotopo berjumlah 165. Proporsi ibu yang memberikan ASI eksklusif adalah 64\%. Besar sampel yang dibutuhkan melalui perhitungan simple random sampling adalah sejumlah 57 responden dengan tingkat kesalahan $5 \%$.

Petugas yang melakukan pengambilan data adalah lulusan D3 Kebidanan dan telah dilakukan diskusi untuk menyatukan persepsi sebelum melakukan pengambilan data. Variabel yang diteliti adalah sosial budaya yang meliputi kepercayaan dan tradisi terkait pemberian ASI eksklusif. Kuesioner terdiri atas 10 pertanyaan, 5 tentang kepercayaan dan 5 tentang tradisi. Setiap pertanyaan akan mempresentasikan tradisi dan kepercayaan yang ada dikeluarga terkait pemberian ASI. Terdapat 2 pilihan jawaban untuk setiap pertanyaan yaitu ya dan tidak. Responden menjawab sesuai dengan keadaan yang ada di keluarganya.

Pengkategorian berdasarkan jawaban responden. Apabila minimal diperoleh 3 jawaban ya maka masuk ke kategori ya. Sedangkan apabila memperoleh minimal 3 jawaban tidak maka masuk ke dalam kategori tidak. Kategori ya adalah keluarga yang memiliki kepercayaan dan tradisi yang kurang mendukung terkait ASI eksklusif. Sementara kategori tidak yaitu untuk keluarga yang tidak memiliki kepercayaan dan tradisi terkait ASI eksklusif.

Hasil kemudian dianalisis menggunakan uji chi square dengan bantuan aplikasi statistik di komputer. Data yang dihasilkan dianalisis untuk mengetahui hubungan pemberian ASI eksklusif dengan kepercayaan dan tradisi.

\section{HASIL PENELITIAN}

Pada penelitian ini dilakukan pengumpulan data dari 57 responden. Dari data yang diperoleh, diketahui bahwa hanya 5 responden yang melakukan ASI eksklusif. Responden yang berhasil melakukan ASI eksklusif adalah yang telah menyusui bayinya sejak lahir hingga usia 6 bulan pertama tanpa tambahan makanan atau minuman apapun. Umur responden terbanyak adalah pada kelompok 20-30 tahun. Pendidikan responden terbanyak dengan jumlah yang sama banyaknya yaitu SD dan SMP sebanyak 21(36,84\%) responden. Pekerjaan responden terbanyak adalah sebagai ibu rumah tangga yaitu $42(73,7 \%)$ responden.

Tabel 1. Karakteristik Responden

\begin{tabular}{lccc}
\hline & \multicolumn{3}{c}{ Pemberian ASI eksklusif } \\
\cline { 2 - 4 } & $\begin{array}{l}\text { Ya } \\
(\boldsymbol{\%})\end{array}$ & $\begin{array}{l}\text { Tidak } \\
(\boldsymbol{\%})\end{array}$ & $\begin{array}{l}\text { Total } \\
(\boldsymbol{\%})\end{array}$ \\
\hline Umur & & & \\
< 20 tahun & 0 & 2 & 2 \\
20-30 & $(0,00)$ & $(100)$ & $(100)$ \\
tahun & 3 & 26 & 29 \\
31-40 & $(10,34)$ & $(89,66)$ & $(100)$ \\
tahun & $(5,56)$ & $(94,44)$ & $(100)$ \\
& 1 & 7 & 8 \\
$>$ 40 tahun & $(12,50)$ & $(87,50)$ & $(100)$ \\
\hline Pendidikan & \multicolumn{3}{c}{} \\
Tidak & 0 & 2 & 2 \\
Sekolah & $(0,00)$ & $(100)$ & $(100)$ \\
SD & 1 & 20 & 21 \\
& $(4,76)$ & $(95,24)$ & $(100)$ \\
SMP & 4 & 17 & 21 \\
& $(19,05)$ & $(80,95)$ & $(100)$ \\
SMA/SMK & 0 & 13 & 13 \\
& $(0,00)$ & $(100)$ & $(100)$ \\
\hline Pekerjaan & \multicolumn{3}{c}{} \\
Ibu Rumah & 4 & 38 & 42 \\
Tangga & $(9,52)$ & $(90,48)$ & $(100)$ \\
Karyawan & 0 & 8 & 8 \\
Swasta & $(0,00)$ & $(100)$ & $(100)$ \\
Wiraswasta & 1 & 6 & 7 \\
& $(14,29)$ & $(85,71)$ & $(100)$ \\
\hline
\end{tabular}


Tabel 2. Kepercayaan dan Tradisi Responden terkait ASI Eksklusif

\begin{tabular}{lccc}
\hline \multicolumn{1}{c}{ Variabel } & $\begin{array}{c}\text { Jawaban } \\
\text { Ya(\%) }\end{array}$ & $\begin{array}{c}\text { Jawaban } \\
\text { Tidak(\%) }\end{array}$ & $\begin{array}{c}\text { Total } \\
(\%)\end{array}$ \\
\hline Kepercayaan Keluarga & $39(68,42)$ & $18(31,58)$ & $57(100)$ \\
$\quad$ Bayi menangis karena lapar & $36(63,16)$ & $21(36,16)$ & $57(100)$ \\
$\quad$ Kepercayaan memberi madu dan air kelapa pada bayi & $26(45,61)$ & $31(54,39)$ & $57(100)$ \\
$\quad$ Menyusui merubah bentuk payudara & $24(42,11)$ & $33(57,39)$ & $57(100)$ \\
Makanan pantangan untuk ibu menyusui & $43(75,44)$ & $14(24,56)$ & $57(100)$ \\
Percaya dan melaksanakan kepercayaan yang ada & & & \\
Tradisi keluarga & $38(66,67)$ & $19(33,33)$ & $57(100)$ \\
Mengikuti tradisi berkaitan dengan menyusui & $35(61,40)$ & $22(38,60)$ & $57(100)$ \\
Tradisi yang bertentangan dengan petugas kesehatan & $29(50,88)$ & $28(49,12)$ & $57(100)$ \\
Memberi madu pada bayi & $31(54,39)$ & $26(45,61)$ & $57(100)$ \\
Memberi pisang dan bubur pada bayi & $35(61,40)$ & $22(38,60)$ & $57(100)$ \\
\hline Memberi makanan pada bayi secepatnya & &
\end{tabular}

Tabel 2 menunjukkan hasil dari rekap jawaban dari responden tentang tradisi dan kepercayaan yang ada di keluarga terkait ASI eksklusif. Diketahui bahwa kepercayaan yang paling banyak ada dikeluarga responden adalah bahwa bayi menangis karena lapar dan kepercayaan untuk memberi madu dan air kelapa pada bayi segera setelah lahir.

Pada hasil rekap diketahui bahwa sebanyak $43(75,44 \%)$ responden menyatakan percaya dan melaksanakan kepercayaan yang ada di keluarga. Hasil menunjukkan bahwa sebanyak $39(68,42 \%)$ respondem menjawab ya mengenai bayi menangis karena lapar sehingga ibu percaya harus segera memberi bayinya makan agar tenang dan tidak rewel. Selain itu diketahui bahwa adanya kepercayaan untuk memberi madu dan air kelapa sesaat setelah bayi lahir, dibuktikan dengan sebanyak 36 $(63,16 \%)$ responden memberikan jawaban ya.

Sebanyak $31 \quad(54,39 \%)$ responden menyatakan bahwa tidak ada kepercayaan tentang menyusui dapat merubah bentuk payudara. Begitu juga dengan kepercayaan keluarga terkait makanan pantangan bagi ibu yang menyusui, sebanyak $33 \quad(57,39 \%)$ responden menjawab tidak. Artinya kepercayaan tersebut sudah mulai tidak dipercaya oleh keluarga.

Ada beberapa tradisi keluarga terkait hal yang kurang mendukung pelaksanaan ASI eksklusif. Dari keseluruhan jawaban responden untuk tiap tradisi yang ada, diketahui bahwa lebih banyak yang menjawab ya daripada yang menjawab tidak. Sebanyak $38 \quad(66,67 \%)$ responden menyatakan bahwa mengikuti tradisi keluarga yang berkaitan dengan menyusui bayinya. Selain itu $35(61,40 \%)$ responden menyatakan bahwa beberapa tradisi yang ada bertentangan dengan saran ataupun informasi yang diberikan oleh petugas kesehatan. Tradisi yang ada di dalam keluarga antara lain adalah memberi madu pada bayi, memberi pisang dan bubur pada bayi dan memberi makanan pada bayi secepatnya. Tradisi tersebut tentunya sangat tidak mendukung terhadap keberhasilan pelaksanaan ASI eksklusif.

\section{Hubungan Kepercayaan dan Tradisi Keluarga dengan Pemberian ASI Eksklusif}

Terdapat 46 responden $(80,7 \%)$ yang masuk ke dalam kategori ya, yaitu memiliki kepercayaan yang kurang mendukunng ASI eksklusif. Sementara 11 (19,3\%) responden lain masuk dalam kategori tidak yang artinya tidak memiliki kepercayaan yang kurang mendukung terkait pemberian ASI eksklusif. Untuk variabel tradisi terdapat 46 responden yang termasuk dalam kategori ya, yaitu memiliki tradisi dalam keluarga terkait pemberian ASI tersebut. Sebanyak 11 responden masuk dalam kategori tidak, yang artinya tidak memiliki tradisi yang kurang mendukung pemberian ASI eksklusif di dalam keluarganya. Kategori kepercayaan dan tradisi ya adalah responden yang memiliki 3 jawaban ya dari 5 hal terkait kepercayaan dan tradisi. Kategori tidak adalah responden yang memiliki 3 jawaban tidak dari 5 hal terkait kepercayaan dan tradisi. 
Hasil uji statistik diperoleh nilai $p$ value $=$ 0,045 (variabel kepercayaan) dan $p$ value $=$ 0,019 (variabel tradisi) hal tersebut menunjukkan bahwa kedua nilai $p$ value $<\alpha$ $(0,05)$ sehingga ada hubungan antara kepercayaan dan tradisi dengan pemberian ASI eksklusif.

Tabel 3. Hubungan Kepercayaan dan Tradisi dengan Keberhasilan ASI Eksklusif

\begin{tabular}{|c|c|c|c|c|}
\hline \multirow[b]{2}{*}{ Kepercayaan } & \multicolumn{2}{|c|}{ ASI eksklusif } & \multirow{2}{*}{$\begin{array}{c}\text { Total } \\
(\%)\end{array}$} & \multirow{2}{*}{$\begin{array}{c}p \text { - } \\
\text { value }\end{array}$} \\
\hline & $\begin{array}{l}\mathbf{Y a} \\
(\%)\end{array}$ & $\begin{array}{c}\text { Tidak } \\
(\%)\end{array}$ & & \\
\hline $\mathrm{Ya}$ & $\begin{array}{c}2 \\
(4,35)\end{array}$ & $\begin{array}{c}44 \\
(95,65)\end{array}$ & $\begin{array}{c}46 \\
(100)\end{array}$ & \multirow{2}{*}{0,045} \\
\hline Tidak & $\begin{array}{c}3 \\
(27,27)\end{array}$ & $\begin{array}{c}8 \\
(72,73)\end{array}$ & $\begin{array}{c}11 \\
(100)\end{array}$ & \\
\hline \multicolumn{5}{|l|}{ Tradisi } \\
\hline Ya & $\begin{array}{c}1 \\
(2,44)\end{array}$ & $\begin{array}{c}40 \\
(97,56)\end{array}$ & $\begin{array}{c}41 \\
(100)\end{array}$ & \multirow{2}{*}{0,019} \\
\hline Tidak & $\begin{array}{c}4 \\
(25,00)\end{array}$ & $\begin{array}{c}12 \\
(75,00)\end{array}$ & $\begin{array}{c}16 \\
(100)\end{array}$ & \\
\hline
\end{tabular}

\section{PEMBAHASAN}

Analisis menunjukkan adanya hubungan antara kepercayaan dan tradisi di dalam keluarga berhubungan dengan keberhasilan ibu dalam melakukan ASI eksklusif di RW XI kelurahan Sidotopo, kecamatan Semampir, Jawa Timur.

Sebagian besar responden termasuk dalam rentang umur yang masih muda. Pada usia ini sangat besar kemungkinan ibu dapat memberikan ASI pada bayinya secara eksklusif karena dirasa masih mampu untuk melakukannya. Pendidikan seluruh responden yang diperoleh dalam penelitian mayoritas masih relatif rendah. Sehingga besar kemungkinan keterbukaan untuk menyerap informasi yang diberikan petugas kesehatan mengenai ASI eksklusif masih kurang. Mayoritas pekerjaan responden adalah ibu rumah tangga. Hal tersebut menunjukkan bahwa ibu memiliki waktu yang banyak untuk dirumah sehingga memiliki lebih banyak peluang untuk dapat menyusui anaknya.

Kepercayaan dan tradisi yang ada secara langsung maupun tidak langsung kurang mendukung terhadap pelaksanaan ASI eksklusif. Ada berbagai macam keyakinan budaya terkait menyusui, ada beberapa keyakinan yang mendukung namun ada juga yang tidak mendukung. Standar budaya dan sosial yang ada di masyarakat berbeda-beda antar setiap tergantung tiap masyara. Hal ini menunjukkan bahwa seharusnya kebijakan kesehatan masyarakat di seluruh dunia harus mempertimbangkan dan mempelajari budaya masyarakat untuk mencipkaan kondisi yang mendukung terhadap praktik pemberian ASI.

Tradisi dan kepercayaan berkembang sebagai sesuatu yang akan menggiring perilaku masyarakat untuk melakukan hal sesuai dengan tradisi dan kepercayaan yang ada di lingkungan mereka. Seperti menurut Hatta (2010), mitosmitos ataupun kepercayaan adalah hal yang menghambat tindakan menyususi yang normal, beberapa mitos yang sering ada yaitu kolostrum yang terdapat dalam ASI tidak bagus dan berbahaya untuk bayi, teh khusus atau cairan dibutuhkan bayi sebelum menyusu, dan bayi akan mengalami kekurangan nutrisi untuk pertumbuhannya apabila hanya diberikan ASI saja. Dari beberapa kepercayaan tersebut tentu seorang ibu akan memberikan beberapa makanan tambahan lain selain ASI untuk memenuhi kebutuhan nutrisi bagi bayinya.

Pemberian ASI eksklusif tidak hanya dipengaruhi dari kerakteristik faktor internal ibu namun dipengaruhi juga oleh faktor eksternal. Salah satunya adalah sosial budaya yang dapat mempengaruhi ibu dalam hal yang berkaitan dengan keberhasilan ibu menyusui secara eksklusif. Menurut Rhokliana, et.al (2011), terdapat hubungan antara sosial budaya terhadap perilaku ibu dalam menyusui bayinya, kebiasaan ibu menyusui dipengaruhi oleh dukungan keluarga kepada ibu.

Menurut penelitian Ramadhany (2016), ibu yang memiliki bayi dibawah usia 1tahun lebih mempercayai dan meyakini nilai dan norma yang berlaku dimasyarakat untuk menentukan pandangannya terkait cara menyusui bayi. Begitu juga dengan yang dikemukan oleh Nuraeni (2008), jika pemberian makanan prelakteal sejak dini merupakan kebiasaan keluarga dan masyarakat turun temurun sambil menunggu ASI keluar, mereka beranggapan dengan memberi makanan sejak dini membuat bayi tidak rewel, tidak cepat lapar, dan pertumbuhan bayi lebih cepat. Ibu yang baru melahirkan lebih percaya pada kebiasaan keluarga atau orang tuanya yang dilakukan turun temurun dari pada mengaplikasikan informasi dari petugas kesehatan. 
Mayoritas penduduk yang tinggal di wilayah kelurahan Sidotopo, adalah para warga pendatang dari suku madura yang memilih menetap di Jawa. Masyarakat madura terkenal dengan budaya-budayanya yang masih sangat kental. Kepercayaan dan tradisi yang ada akan mempengaruhi perilaku masyarakatnya. Kepercayaan di dalam sosial budaya datang dari apa yang dilihat dan apa yang diketahui seseorang. Kepercayaan yang telah diyakini oleh seseorang akan menjadi dasar untuk berperilaku. Namun pada kenyataannya tidak selalu kepercayaan tersebut benar. Ada kalanya karena ketidaktahuan akan informasi yang benar mengenai suatu kejadian atau objek yang terjadi justru membentuk sebuah kepercayaan (Azwar, 2005).

Menurut sebuah penelitian yang dilakukan di Thailand pada tahun 2015 oleh Dornan, et.al., diketahui bahwa budaya yang ada di masyarakat Thailand mempengaruhi kebiasaan ibu dalam menyusui anaknya. Ada 3 hal dari budaya yang ditemukan dalam penelitian tersebut yang mempengaruhi perilaku individu. Budaya tersebut yaitu budaya nasional, budaya organisasi dan budaya individu. Dorman menemukan bukti bahwa budaya yang dipercaya oleh masyarakat memunculan sebuah filosofi yang akan menggiring perilaku masyarakat di sebuah organisasi. Perilaku tersebut akan dilakukan setiap hari dan turun temurun didalam organisasi sehingga akan menjadi tradisi. Tradisi ini yang akan mempengaruhi setiap individu untuk ikut melakukannya.

Beberapa penelitian dilakukan untuk mengetahui pengaruh budaya dengan perilaku masyarakat yang sudah tinggal lama di suatu wilayah. Tetapi belum banyak yang meneliti tentang pengaruh perbedaan budaya yang ada antara wilayah asal dengan tempat tinggal selanjutnya. Salah satu penelitian yang sudah dilakukan oleh Saaty, et.al. (2015), dengan tujuan untuk mengetahui praktik menyusui dikalangan imigran yang berasal dari Arab dan tinggal di Amerika Serikat. Penelitian tersebut menemukan fakta bahwa adanya perbedaan persepsi dan budaya antara negara asal dengan negara tempat tinggal sekarang mempengaruhi perilaku ibu-ibu dalam menyusui bayinya. Perilaku dibentuk oleh budaya dan nilai-nilai serta kenyakinan agama para ibu-ibu Arab ini berkembang dengan adanya perbedaan persepsi serta budaya ditempat mereka tinggal sekarang.
Dari penelitian tersebut dapat diketahui bahwa budaya yang ada disuatu tempat baru berhubungan dengan perilaku masyarakat pendatang yang tinggal diwilayah tersebut. Perbedaan persepsi mempengaruhi pandangan seseorang untuk beradaptasi dan menyesuaikan dengan budaya yang ada ditempat barunya. Budaya di tempat baru mendorong seseorang untuk mengikutinya, disitulah muncul beberapa kepercayaan yang berkembang dimasyarakat.

Kepercayaan dan tradisi yang ada di masyarakat menggiring pola pikir masyarakat atas tindakan yang akan dilakukan untuk menyikapi sesuatu. Kepercayaan yang ada di masyarakat menjadi hal yang sangat berperan dalam membentuk perilaku seseorang.

Hal ini mungkin dapat terjadi karena responden kurang mengetahui fakta yang sebenarnya dibalik kepercayaan tersebut. Sebagai contoh, apabila responden sudah sejak sebelum melahirkan percaya bahwa memberikan cairan lain selain air susu ibu seperti madu atau air manis ketika bayi lahir dapat membuat bayi menjadi lebih kuat. Maka responden tersebut akan menanamkan bahwa memberi madu dan air manis dapat akan membuat bayi menjadi lebih kuat. Kepercayaan ini dapat dengan mudah melemahkan terlaksanakannya ASI eksklusif yang seharusnya menyusui bayi dengan air susu ibu saja dari lahir hingga umur 6 bulan pertama.

Sistem pencernaan yang dimiliki bayi baru lahir masih belum kuat. Sehingga bayi dikhawatirkan belum mampu untuk mencerna makanan lain selain ASI. Kandungan ASI juga sudah mencukupi seluruh kebutuhan nutrisi yang diperlukan bayi. Namun masyarakat biasanya sudah terlanjur percaya dengan informasi yang berkembang dimasyarakat. Banyak para ibu yang memberikan makanan pendamping kepada bayinya yang baru berusia dua bulan karena ketidak tahuan ibu akankegunaan ASI. Beberapa riset yang dilakukan di beberapa negara membuktikan bahwa ASI adalah nutrisi paling baik untuk bayi sampai usia 6 bulan pertama kemudian disempurnakan hingga 2 tahun selanjutnya (Media Indonesia, 2008).

Kepercayaan mengenai makanan pantangan bagi ibu yang menyusui juga tidak memiliki dasar yang sesuai. Justru ibu yang sedang menyusui memerlukan banyak nutrisi tidak hanya untuk dirinya tetapi untuk bayi yang akan mendapatkan nutrisi dari ASI yang diberikan ibu. Salah satu nutrisi yang 
diperlukan ibu adalah protein. Makanan tertentu seperti ikan, makanan laut dan cumicumi merupakan makanan yang mengandung protein cukup tinggi. Sehingga nutrisi tersebut baik untuk ibu asal dikonsumsi dengan porsi yang wajar dan tidak berlebihan.

Sebuah studi yang dilakukan Daglas \& Antoniou (2012) di Athens, Greece, ditemukan hasil bahwa proses menyusui seringkali tidak ditentukan oleh faktor biologis, tetapi terutama didasarkan pada kebiasaan, tradisi dan perilaku yang ada di masyarakat. Tradisi merupakan perilaku sosial dimana perilaku itu diturunkan dari generasi ke generasi selanjutnyadengan melewati sebuah proses sosialisasi. Nilai-nilai dan moral masyarakat ditentukan oleh sebuah tradisi, karena tradisi berisi aturan menurut warga masyarakat mengenai hal yang seharusnya dilakukan.

Kebiasaan dilakukan turun temurun dan dijalankan oleh masyarakat, mereka menilai dan beranggapan apabilakebiasaan diturunkan adalah sesuatu yang paling benar dan baik. Yusrina \& Devy (2016), menyatakan bahwa keyakinan dan keinginan meniru yang dimiliki oleh ibu mempengaruhi niat ibu dalam menyusui bayinya. Niat responden untuk melakukan ASI eksklusif dipengaruhi oleh keyakinan dan keyakinan ibu itu sendiri. Secara logika adanya tradisi di kelurahan Sidotopo terkait pemberian ASI tentu berkaitan erat dengan niat dan harapan ibu dalam keberhasilan menyusui secara eksklusif.

Hasil dari penelitian ini memiliki kekuatan karena benar-benar diambil di daerah dengan capaian ASI eksklusif yang masih rendah. Namun karena keterbatasan peneliti membuat responden dalam penelitian ini cenderung sedikit sehingga hasil analisis hubungan yang diperoleh relatif signifikan. Lokasi yang diambil dalam penelitian ini juga hanya $1 \mathrm{RW}$ sehingga hasil sulit untuk digeneralisasikan secara umum.

Pelaksanaan ASI secara eksklusif adalah salah satu program yang ditujukan untuk menurunkan angka kematian bayi dengan memberikan nutrisi yang terbaik bagi bayi melalui ASI. Selain itu pemberian ASI secara eksklusif juga sudah diatur langsung didalam UU Republik Indonesia Nomor 36 Tahun 2009 tentang Kesehatan dan Peraturan Pemerintah Nomor 33 Tahun 2012. Bahkan didalam buku KIA yang diberikan kepada ibu hamil ketika periksa hamil juga sudah dituliskan bahwa ASI eksklusif merupakan hak yang seharusnya diperoleh bayi.

\section{SIMPULAN DAN SARAN}

\section{Simpulan}

Ada 5 ibu menyusui atau sebesar 8,87\% yang memberikan ASI eksklusif. Sebanyak 46 $(80,70 \%)$ ibu menyusui masih memiliki kepercayaan dan $41(71,93 \%)$ ibu menyusui memiliki tradisi yang kurang mendukung ASI eksklusif. Ada hubungan antara kepercayaan dan tradisi keluarga dengan pemberian ASI eksklusif. Kepercayaan dan tradisi yang kurang mendukung tersebut merupakan salah satu faktor penghambat pemberian ASI eksklusif.

\section{Saran}

Diperlukan penyuluhan yang melibatkan beberapa pihak dan lintas sektor seperti Puskesmas, Dinas Kesehatan dan Perangkat Desa. Tujuan dari penyuluhan untuk mengubah persepsi masyarakat tentang kepercayaan dan tradisi yang ada terkait pemberian ASI eksklusif. Penyuluhan dapat dilakukan dengan menggunakan media yang menarik dan mudah dipahami oleh masyarakat. Contohnya dengan melalui video pendek yang membandingkan mitos dan fakta tentang pemberian ASI eksklusif. Perlu dilakukan penelitian lebih jauh untuk mengetahui cara pendekatan untuk merubah persepsi yang sesuai dengan keadaan di masyarakat. Selain itu perlu adanya studi intervensi terkait media informasi atau cara pendekatan dan program pelayanan yang sudah diberikan terkait pemberian ASI eksklusif.

\section{DAFTAR PUSTAKA}

Azwar, S. 2005. Sikap Manusia: Teori dan Pengukurannya. Yogyakarta: Pustaka Pelajar.

Daglas, M., Antoniou, E. 2012. Cultural Views and Practices Related to Breastfeeding. Health Science Journal, [e-journal] 6 (2): pp. 353-361.

Depkes RI. 2009. Strategi Nasional Peningkatan Pemberian Air Susu Ibu (PPASI). Jakarta: Depkes RI.

Dinkes Provinsi Jawa Timur. 2016. Profil Kesehatan Provinsi Jawa Timur Tahun 2016. Surabaya: Dinas Kesehatan Provinsi Jawa Timur.

Dornan, L., Sinclair, M., Kernohan, W.G., 
Stockdale, J., Khuwuthyakorn, V., Suppasan, P. 2015. Thai Cultural Influences on Breastfeeding Behaviour. Evidence Based Midwifery, [e-journal] 13 (3): pp. 84-91.

Hatta, G.R. 2011. Pedoman Manajemen Informasi Kesehatan di Sarana Pelayanan Kesehatan. Jakarta: UI-Press.

Ludin, H.B. 2009. Pengaruh Sosial Budaya masyarakat terahadap Tindakan Pemberian ASI Eksklusif di wilayah Kerja Puskesmas Kecamatan Rumbai Pesisir Kota Pekan Baru. Tesis. Universitas Sumatra Utara.

Nuraeni. 2008. Hubungan Dukungan Keluarga Terhadap Pemberian ASI Eksklusif di Kecamatan Sossa Kabupaten Padang Lawas. Skripsi. Universitas Sumatera Utara.

Peraturan Pemerintah Republik Indonesia Nomor 33 Tahun 2012 Tentang Pemberian Air Susu Ibu Eksklusif. Jakarta: Kementerian Kesehatan Republik Indonesia.

Ramadhany, T. 2016. Hubungan Sosial Budaya terhadap Pemberian Asi Eksklusif pada Bayi di Kecamatan Medan Amplas. Skripsi. Universitas Sumatera Utara.

Rhokliana, Aisyah, S., Chandradewi, A.A.S.P. 2011. Hubungan Sosial Budaya dengan Pemberian Asi pada Bayi di Wilayah Kerja Puskesmas Keruak Kabupaten Lombok Timur. Jurnal Kesehatan Prima, [e-journal] 5 (2): pp. 765-777.

Roesli. 2009. Mengenal ASI Eksklusif. Jakarta:
PT Puskata Pembangunan Swadaya Nusantara.

Saaty, H.A., Joan, C., Christine, K. 2015. Practicesof Breastfeeding among Arab Mothers Living in the United States. World Journal of Medical Sciences, [e-journal] 12 (2): pp. 183-188.

Simbolon, Demsa. 2006. Kelangsungan Hidup Bayi di Perkotaan dan Pedesaan Indonesia. Jurnal Kesehatan Masyarakat Nasional, [ejournal] 1 (1): pp. 3-10.

Soetjiningsih. 2012. ASI Petunjuk untuk Tenaga Kesehatan. Jakarta: Buku Kedokteran EGC.

Undang-Undang Republik Indonesia Nomor 36 Tahun 2009 Tentang Kesehatan. Jakarta: Kementerian Kesehatan Republik Indonesia.

UNICEF. 2016. Jutaan Bayi di Indonesia Kehilangan Awal Terbaik dalam Hidup Mereka. [online] Jakarta: UNICEF Indonesia.

Widodo, J. 2006. Penghambat ASI Ekslusif Itu Masih Banyak Controversies in Child Health, Center for Research and Development of Nutrition and Food. Jakarta: NIHRD.

Yusrina, A., Devy, S.R. 2016. Faktor yang Mempengaruhi Niat Ibu Memberikan Asi Eksklusif di Kelurahan Magersari, Sidoarjo. Jurnal Promosi dan Pendidikan Kesehatan Indonesia, [e-journal] 4 (1): pp. 11-21. 